\title{
Optimization of Methodology for Determination of Inorganic Chromium Species in Sewage Sludge Samples by HPLC-ICP-MS/MS
}

\author{
Érica S. Barbosa, ${ }^{a}$ Ane P. Cacique, ${ }^{a}$ Gevany P. de Pinho ${ }^{a}$ and \\ Flaviano O. Silvério ${ }^{\circledR *, a}$ \\ anstituto de Ciências Agrárias, Universidade Federal de Minas Gerais, \\ 39404-547 Montes Claros-MG, Brazil
}

\begin{abstract}
This study developed a methodology for extracting and speciating $\mathrm{Cr}^{\mathrm{III}}$ and $\mathrm{Cr}^{\mathrm{VI}}$ in sewage sludge by high performance liquid chromatography, inductively coupled plasma tandem mass spectrometry (HPLC-ICP-MS/MS). The optimal procedure was solid-liquid extraction in a water bath with stirring at $50{ }^{\circ} \mathrm{C}$ for $16 \mathrm{~h}$ and $50 \mathrm{mmol} \mathrm{L}^{-1}$ ethylenediaminetetraacetic acid (EDTA) extraction phase at $\mathrm{pH}$ 9.5. In the validated method, the recovery in the fortification experiment was greater than $70 \%$ and the relative standard deviation was less than $7 \%$. Speciation analyses showed that all $\mathrm{Cr}^{\mathrm{VI}}$ was spontaneously reduced to $\mathrm{Cr}^{\mathrm{III}}$ in the sludge sample. The limits of detection and quantification were 0.060 and $0.20 \mu \mathrm{g} \mathrm{L}^{-1}$, respectively, and the analyses of $\mathrm{Cr}^{\mathrm{III}}$ by means of ICP-MS/MS were linear from 0.20 to $50 \mu \mathrm{g} \mathrm{L}^{-1}$. The extraction efficiency of Cr specie in this validated method improved from 4.09 to $53.3 \%$ compared to the EPA 1311 method. The methodology was successfully applied to quantify $\mathrm{Cr}^{\mathrm{III}}$ in a sludge sample with a lower concentration than that established by European legislation 80568/4225/91.
\end{abstract}

Keywords: sewage sludge, chromium, extraction, reduction, inorganic chromium species

\section{Introduction}

Sewage sludge is a solid material resulting from effluent treatment at sewage treatment plants. ${ }^{1}$ This material has been used in farming as a fertilizer or soil amendment due to the high content of macro and micronutrients and particularly for organic matter. ${ }^{2}$ However, sludge may also have organic and inorganic contaminants in its chemical composition. ${ }^{1}$

Inorganic contaminants are generally toxic metals such as $\mathrm{As}, \mathrm{Cd}, \mathrm{Pb}, \mathrm{Hg}$ and $\mathrm{Cr}$. In addition, $\mathrm{Cr}$ may be found in the environment in oxidation (III) and (VI) states. ${ }^{1,3} \mathrm{Cr}^{\mathrm{III}}$ in low concentrations is not toxic to human beings or the environment, and is additionally important for human metabolism. ${ }^{4}$ On the other hand, $\mathrm{Cr}^{\mathrm{VI}}$ is highly toxic and is generally related to health problems such as carcinogenesis and mutagenicity. ${ }^{5}$

Therefore, environmental laws are very strict in monitoring $\mathrm{Cr}^{\mathrm{VI}}$ levels in food and environmental matrices. ${ }^{6}$ Resolution No. 375 of the National Environment Council (CONAMA) ${ }^{7}$ in Brazil currently establishes $1000 \mathrm{mg} \mathrm{kg}^{-1}$ as the limiting concentration of total $\mathrm{Cr}$ in the sewage sludge. However, the maximum permitted concentrations

*e-mail: flavianosilverio@ufmg.br of each $\mathrm{Cr}$ species have been set by few countries such as Hungary and Greece, which determine 1 and $10 \mathrm{mg} \mathrm{kg}^{-1}$, respectively, as the limiting $\mathrm{Cr}^{\mathrm{VI}}$ concentration in sewage sludge. . $^{8}$

In order to reach these limits, several extraction methodologies have been developed for this metal to determine $\mathrm{Cr}^{\mathrm{VI}}$ in matrices such as water, ${ }^{10}$ soils, ${ }^{11,12}$ and foods of plant, animal and industrial origin. ${ }^{13-15}$ In determining $\mathrm{Cr}^{\mathrm{III}}$ and $\mathrm{Cr}^{\mathrm{VI}}$ in environmental samples, it is common to separate the chromium species in the extraction stage. ${ }^{6}$ Thus, methodologies involving precipitation or cartridges containing adsorbents have been used for separating $\mathrm{Cr}^{\mathrm{III}}$ and $\mathrm{Cr}^{\mathrm{VI}}$, then the extracts obtained with each chemical species are analyzed by instrumental techniques such as atomic absorption spectrometry (AAS), graphite furnace atomic absorption spectrometry (GFAAS) and inductively coupled plasma mass spectrometry (ICPMS). ${ }^{16-19}$ However, there are no extraction methodologies for sewage sludge samples which enable the simultaneous quantification of $\mathrm{Cr}^{\mathrm{III}}$ and $\mathrm{Cr}^{\mathrm{VI}}$.

In the past, the US Environmental Protection Agency (US EPA) has defined a methodology known as the toxicity characteristic leaching procedure (TCLP) to determine the mobility of toxic contaminants such as $\mathrm{Cr}$ in liquid and solid waste through the EPA protocol $1311 .^{20}$ 
In this method, it is common to quantify $\mathrm{Cr}$ in extracts by inductively coupled plasma optical emission spectrometry (ICP OES). ${ }^{21,22}$

However, it is necessary to use separation techniques such as high performance liquid chromatography (HPLC), followed by a detection technique such as inductively coupled plasma tandem mass spectrometer (ICP-MS/MS) ${ }^{13}$ for simultaneous analysis of each $\mathrm{Cr}$ species at trace levels. In addition, the use of the ICP-MS/MS as a detector enables greater selectivity during the analysis, because it is possible to filter the target analyte with the second quadrupole (MS/MS) and eliminate the interfering ions. ${ }^{23}$

Therefore, the objective of this study was to optimize and validate a methodology based on solid-liquid extraction and HPLC-ICP-MS/MS analysis to determine $\mathrm{Cr}^{\mathrm{III}}$ and $\mathrm{Cr}^{\mathrm{VI}}$ in sewage sludge samples.

\section{Experimental}

\section{Reagents and solutions}

$\mathrm{HCl}(36 \%, v / v)$, glacial $\mathrm{CH}_{3} \mathrm{COOH}$, and pure $\mathrm{HNO}_{3}$ $(65 \%, \mathrm{v} / \mathrm{v})$ acids and $\mathrm{Na}_{2} \mathrm{SO}_{4}$, ethylenediaminetetraacetic acid disodium salt dehydrate (EDTA.2Na), NaOH, $\mathrm{NaH}_{2} \mathrm{PO}_{4}, \mathrm{Cr}\left(\mathrm{NO}_{3}\right)_{3}$ and $\mathrm{K}_{2} \mathrm{CrO}_{4}$ reagents were obtained from Sigma-Aldrich (St. Louis, MO, USA) with purity greater than $99 \%(\mathrm{~m} / \mathrm{m})$. The $\mathrm{NH}_{4} \mathrm{OH}(30 \%, \mathrm{v} / \mathrm{v})$ was obtained from Neon (Suzano, SP, Brazil).

The standard $\mathrm{Cr}^{\mathrm{III}}$ and $\mathrm{Cr}^{\mathrm{VI}}$ solutions at the concentration of $1000 \mathrm{mg} \mathrm{L}^{-1}$ were prepared in ultrapure water (Millipore, Burlington, MA, USA) from high purity analytical standards of $\mathrm{Cr}\left(\mathrm{NO}_{3}\right)_{3}$ and $\mathrm{K}_{2} \mathrm{CrO}_{4}$, respectively. These solutions were diluted to prepare the working solutions.

\section{Instrumentation}

In the optimization stage of $\mathrm{Cr}^{\mathrm{III}}$ and $\mathrm{Cr}^{\mathrm{VI}}$, extraction conditions, Scilogex vortex (USA), Unique ultrasonic bath (Brazil), stirring water bath (Nova Ética, Brazil), heating plate (Tecnal, Brazil), Quimis pH meter (Brazil) and Kindly centrifuge (Brazil) were used. A CEM (USA) Mars 6 microwave oven was also used during the work.

\section{Atomic absorption spectrometry analyses}

An atomic absorption spectrophotometer (AAS 240 FS, Varian, Australia) was used to determine the $\mathrm{Cr}$ content in the sludge sample during the extraction method optimization step. Analyses were performed in flame mode using air-acetylene (acetylene 2.8 AA).

\section{HPLC-ICP-MS/MS analyses}

A high performance liquid chromatograph (HPLC 1260 Infinity, Agilent Technologies, Japan) coupled to an inductively coupled plasma-tandem mass spectrometer (ICP-MS/MS 8800, Agilent Technologies, Japan) was used for $\mathrm{Cr}$ speciation. The system was equipped with a G1311B quaternary pump, G1316A column housing and G1329B auto-sampler.

Speciation of $\mathrm{Cr}^{\mathrm{III}}$ and $\mathrm{Cr}^{\mathrm{VI}}$ was performed on an anion exchange chromatographic column of polymethacrylate resin $(30 \times 4.6 \mathrm{~mm}, 10 \mu \mathrm{m})$ (model G3268, Agilent Technologies, Japan). The target-analytes were eluted in the isocratic mode at a flow rate of $1.3 \mathrm{~mL} \mathrm{~min}^{-1}$ with a mobile phase consisting of $5 \mathrm{mmol} \mathrm{L}^{-1}$ EDTA, $15 \mathrm{mmol} \mathrm{L}^{-1}$ $\mathrm{Na}_{2} \mathrm{SO}_{4}$ and $5 \mathrm{mmol} \mathrm{L}-1 \mathrm{NaH}_{2} \mathrm{PO}_{4}$ with $\mathrm{pH} 7$ adjusted with $1.0 \mathrm{~mol} \mathrm{~L}^{-1} \mathrm{NaOH}$ solution. The analyses were performed at $30^{\circ} \mathrm{C}$ and the injection volume was $100 \mu \mathrm{L}$.

The ICP-MS/MS operating conditions were set for $1550 \mathrm{~W}$ radio frequency, $15 \mathrm{~L} \mathrm{~min}^{-1}$ plasma $\operatorname{argon}$ gas flow, $1.1 \mathrm{~L} \mathrm{~min}^{-1}$ charger gas rate, and $0.9 \mathrm{~L} \mathrm{~min}^{-1}$ auxiliary gas, while the sampling depth was $8 \mathrm{~mm}$ and the temperature was set at $2{ }^{\circ} \mathrm{C}$ in the nebulization chamber. Nickel cone skimmer and sampler were used. The collision gas was $99.999 \%$ pure helium and $4.3 \mathrm{~mL} \mathrm{~min}^{-1}$ flow. The quadrupoles were adjusted to monitor the mass $\mathrm{m} / \mathrm{z} 52$ attributed to the most abundant isotope of $\operatorname{Cr}(83.8 \%)$.

\section{Chromium complexation in standard solution}

$\mathrm{Cr}^{\mathrm{III}}$ is poorly soluble in water at $\mathrm{pH} 4$ to 12 and does not elute in the anion exchange chromatographic column. ${ }^{24,25}$ Thus, a complexation step was necessary before HPLC-ICP-MS/MS analysis to convert the $\mathrm{Cr}^{\mathrm{III}}$ in the standard solution to [Cr-EDTA $]^{-}$. The methodology consisted of adding $0.1 \mathrm{~mL}$ of $10 \mathrm{mg} \mathrm{L}^{-1} \mathrm{Cr}^{\text {III }}$ standard solution and $4.9 \mathrm{~mL}$ EDTA solution $\left(15 \mathrm{mmol} \mathrm{L}^{-1}\right)$ with $\mathrm{pH}$ adjusted to 7 using $1.0 \mathrm{~mol} \mathrm{~L}^{-1} \mathrm{NaOH}$ solution. The system was subsequently heated at $60^{\circ} \mathrm{C}$ for $30 \mathrm{~min}$ and dilutions were performed using the mobile phase. ${ }^{26}$ These standard solutions were used to adjust the analysis conditions by means of HPLC-ICP-MS/MS.

\section{Sewage sludge samples}

The sewage sludge samples were obtained from the sewage treatment plant of Montes Claros, Minas Gerais, Brazil. After collection, sewage sludge samples were screened in 2-mm sieves and stored in a refrigerator at $4{ }^{\circ} \mathrm{C}$ until sample preparation. The sewage sludge characteristics 
are shown in Table S1 (Supplementary Information (SI) section). ${ }^{27}$

\section{Extraction method optimization}

\section{Sludge sample fortification}

The extraction of $\mathrm{Cr}^{\mathrm{III}}$ and $\mathrm{Cr}^{\mathrm{VI}}$ from the sludge sample was optimized from fortification and recovery experiments. Hence, samples of $0.200 \mathrm{~g}$ in triplicate were fortified with $0.1 \mathrm{~mL}$ of $250 \mathrm{mg} \mathrm{L}^{-1} \mathrm{Cr}^{\text {III }}$ solution and allowed to stand for $24 \mathrm{~h}$. The same procedure was performed by fortifying sludge samples only with $\mathrm{Cr}^{\mathrm{VI}}$.

\section{Microwave assisted solid-liquid extraction}

Extraction of $\mathrm{Cr}$ species was initially based on the work by Guidotti et al. ${ }^{11}$ Following this methodology, $0.200 \mathrm{~g}$ of fortified sludge sample and $5 \mathrm{~mL}$ of an extractor phase were added to a Teflon tube. This tube was introduced into the microwave oven and the power of the apparatus ranged from 1030 to $1800 \mathrm{~W}$ in $25 \mathrm{~min}$ to reach $100^{\circ} \mathrm{C}$. The system remained at this temperature for $5 \mathrm{~min}$ and then cooled for $15 \mathrm{~min}$. The supernatant was filtered on qualitative filter paper, the final volume was adjusted to $25.00 \mathrm{~mL}$ with ultrapure water, and finally analyzed by means of AAS. Four extractor phases were evaluated based on a previous study, ${ }^{6}$ as can be observed in Table 1.

Table 1. Parameters evaluated in the optimization of $\mathrm{Cr}^{\mathrm{III}}$ and $\mathrm{Cr}^{\mathrm{VI}}$ extraction in sewage sludge samples

\begin{tabular}{|c|c|c|}
\hline $\begin{array}{l}\text { Solid-liquid } \\
\text { extraction }\end{array}$ & Parameter & Level \\
\hline \multirow{4}{*}{$\begin{array}{l}\text { Microwave- } \\
\text { assisted } \\
\text { extraction }\end{array}$} & \multirow{4}{*}{ extractor phase } & $\mathrm{HCl}$ in $\mathrm{pH}=1$ \\
\hline & & $\begin{array}{c}\text { EDTA at } 50 \mathrm{mmol} \mathrm{L}^{-1} \text { in } \mathrm{pH}=7 \\
\text { (adjusted with } \mathrm{NaOH} \text { ) }\end{array}$ \\
\hline & & $\begin{array}{c}\text { EDTA at } 50 \mathrm{mmol} \mathrm{L}^{-1} \text { in } \mathrm{pH}=9.5 \\
\text { (adjusted with } \mathrm{NH}_{4} \mathrm{OH} \text { ) }\end{array}$ \\
\hline & & $\mathrm{NH}_{4} \mathrm{OH}$ in $\mathrm{pH}=10$ \\
\hline \multirow{7}{*}{ Conventional } & \multirow{5}{*}{ homogenization } & plate $(1 \mathrm{~h})$ \\
\hline & & vortex $(5 \min )$ \\
\hline & & ultrasonic bath (30 min) \\
\hline & & vortex/ultrasonic bath $(5 / 30 \mathrm{~min})$ \\
\hline & & shaking water bath at $100 \mathrm{rpm}(24 \mathrm{~h})$ \\
\hline & time $/ \mathrm{h}$ & $1,6,16$ and 24 \\
\hline & temperature $/{ }^{\circ} \mathrm{C}$ & 30,40 and 50 \\
\hline
\end{tabular}

EDTA: ethylenediaminetetraacetic acid.

\section{Conventional solid-liquid extraction}

A new experimental procedure based on conventional solid-liquid extraction was optimized to increase the recovery percentage of $\mathrm{Cr}^{\mathrm{III}}$ and $\mathrm{Cr}^{\mathrm{VI}}$ in the fortified sludge samples.
Therefore, $0.200 \mathrm{~g}$ of fortified sludge sample and $5 \mathrm{~mL}$ of $50 \mathrm{mmol} \mathrm{L}^{-1}$ EDTA solution at $\mathrm{pH} 9.5$ were used. The flask containing the sample and the extraction phase was shaken by different homogenization modes, time and temperature, which are detailed in Table 1. The supernatant was filtered on qualitative filter paper at the end of each extraction, then the final volume was adjusted to $25.00 \mathrm{~mL}$ with ultrapure water and the analyses were performed by AAS.

The recovery data for each parameter evaluated in Table 1 were submitted to analysis of variance (ANOVA) at a 5\% significance $F$-test and the means were compared by the Duncan test using the RStudio statistical software program. ${ }^{28}$

\section{Cr speciation by HPLC-ICP-MS/MS}

Triplicate sludge samples were fortified with standard solution simultaneously containing $\mathrm{Cr}^{\mathrm{III}}$ and $\mathrm{Cr}^{\mathrm{VI}}$ and allowed to stand for $24 \mathrm{~h}$. Then, these samples were subjected to solid-liquid extraction under optimal conditions. The obtained extracts were analyzed by HPLC-ICP-MS/MS to study Cr speciation.

An analytical curve was prepared to determine recovery percentages of each $\mathrm{Cr}$ species by diluting the standard $\mathrm{Cr}^{\mathrm{III}}$ and $\mathrm{Cr}^{\mathrm{VI}}$ solution in sludge extract (matrix calibration) to minimize problems associated with the effect of matrix. Each prepared standard solution was heated at $60{ }^{\circ} \mathrm{C}$ for 30 min prior to HPLC-ICP-MS/MS analysis so that $\mathrm{Cr}^{\mathrm{III}}$ was complexed by EDTA in the matrix extract.

\section{Extraction method validation}

Five validation parameters were evaluated to ensure the reliability of the optimized method results. The limits of detection (LOD), quantification (LOQ), linearity, precision and accuracy were evaluated as recommended by IUPAC..$^{29}$

\section{Comparison between methods}

The total $\mathrm{Cr}$ concentration in a non-fortified sewage sludge sample was obtained using the EPA 3051 A method. ${ }^{30}$ In the same sample, the optimized method and the EPA 1311 reference method ${ }^{20}$ were performed in order to compare the $\mathrm{Cr}$ recovery efficiency by both methods. More details about these methods can be observed in Figure 1.

\section{Application of the method in real sample}

A sludge sample was submitted to the optimized and validated method to determine the $\mathrm{Cr}$ concentration. However, we chose to quantify the species of this metal 

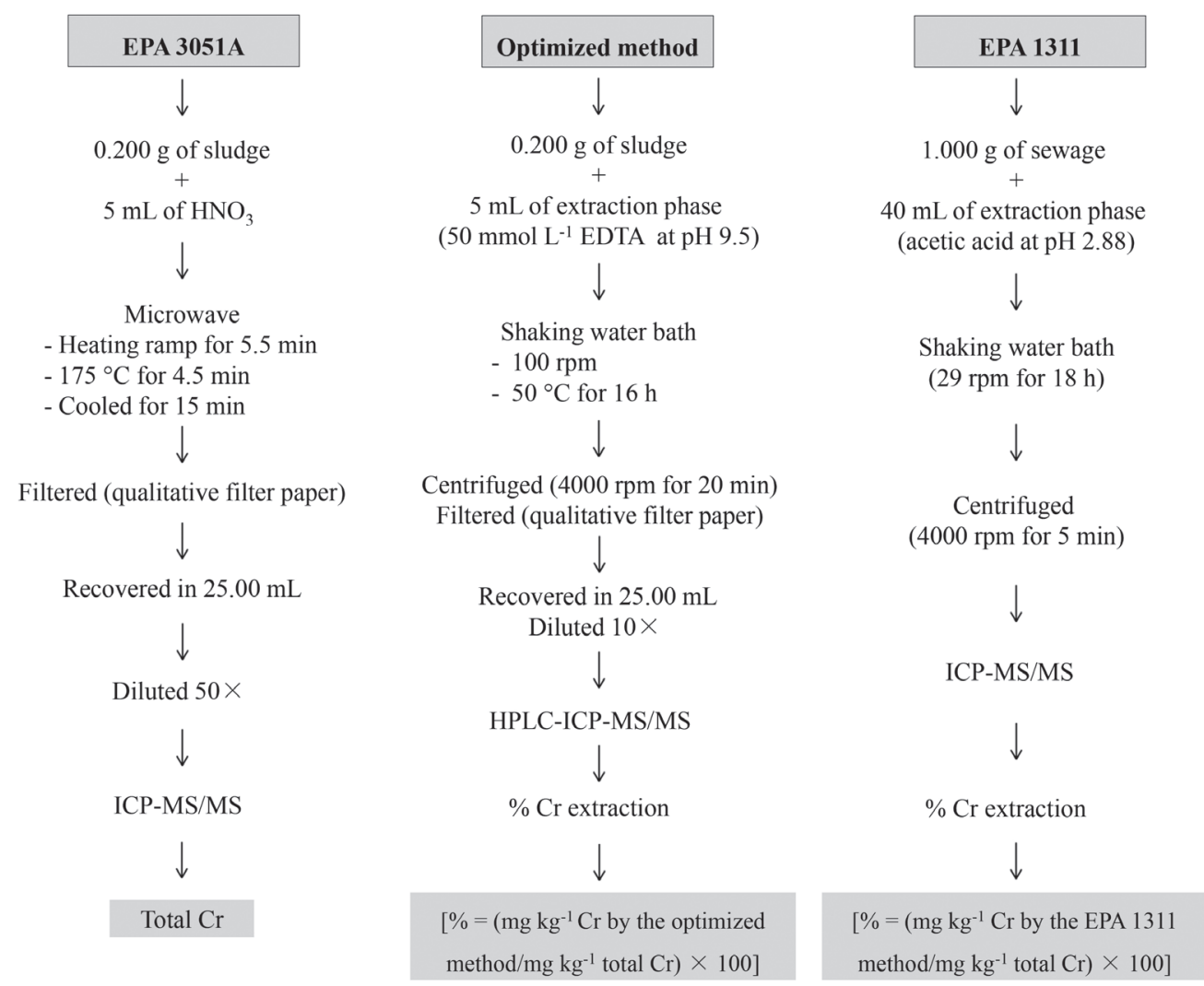

Figure 1. Representation of methodologies used to determine $\mathrm{Cr}$ in a sewage sludge sample: EPA 3051A (total Cr), optimized method (Cr available) and EPA 1311 reference method ( $\mathrm{Cr}$ available).

through the standard addition method due to the problems associated with the matrix effect and the lack of a Cr-free (matrix blank) sludge sample. In this procedure, the sludge sample was divided into three aliquots in which one was not fortified, the second was fortified with $0.1 \mathrm{~mL}$ of $25 \mathrm{mg} \mathrm{L}^{-1} \mathrm{Cr}$ solution, and the third fortified with $0.1 \mathrm{~mL}$ of $\mathrm{Cr}$ solution at $125 \mathrm{mg} \mathrm{L}^{-1}$. They were then subjected to extraction by the optimized method. The obtained extracts were diluted 10 times before the analyses. The $\mathrm{Cr}$ concentration in the sludge sample was obtained by extrapolation of the analytical curve.

\section{Results and Discussion}

\section{Extraction method optimization}

An AAS was preferably used during the optimization of $\mathrm{Cr}$ extraction in sludge samples. This was necessary because the analyses in this equipment represented approximately $95 \%$ savings in gas consumption compared to HPLC-ICP-MS/MS quantifications. However, it is not possible to distinguish $\mathrm{Cr}^{\mathrm{III}}$ from $\mathrm{Cr}^{\mathrm{VI}}$ in instrumental analysis by atomic absorption, so the sludge samples were separately fortified with each species in order to evaluate their recovery individually.
The first optimized solid-liquid extraction was the microwave-assisted extraction phase consisting of $\mathrm{HCl}$ solution at $\mathrm{pH} 1$. However, the obtained recovery was unsatisfactory, being close to $10 \%$ for $\mathrm{Cr}^{\mathrm{III}}$ (Figure 2).

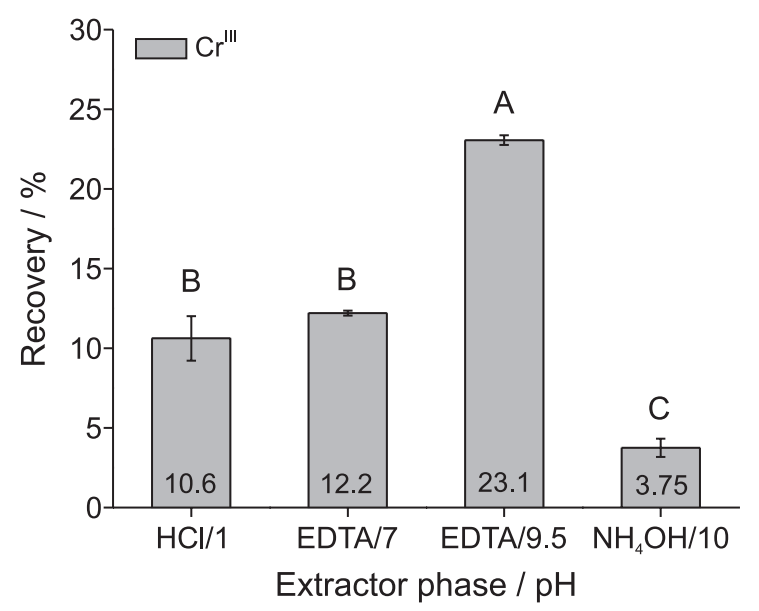

Figure 2. $\mathrm{Cr}^{\mathrm{III}}$ recovery percentage in sludge samples using four microwave extraction phases.

Thus, new extraction phases were evaluated as shown in Table 1. Among the four solutions analyzed, the extraction phase constituted by the $\mathrm{pH} 9.5$ EDTA solution showed the highest $\mathrm{Cr}^{\mathrm{III}}$ recovery percentage, in addition to being 
statistically different from the others. This solution has also been used in previous studies to extract $\mathrm{Cr}$ species from soils ${ }^{11,31}$ and dietary supplements. ${ }^{24}$

Although the change in the extraction phase represented advances in microwave-CrII recovery, $\mathrm{Cr}^{\mathrm{VI}}$ was not extracted under these conditions. Therefore, an alternative was to subject the sample to conventional solid-liquid extraction using the best extraction phase. The first parameter optimized in this method was the homogenization of the sludge-phase extraction system. We evaluated five levels in this parameter, as shown in Table 1 . These types of homogenization were used since they are the most cited in the literature ${ }^{12,14,32}$ for extraction of $\mathrm{Cr}$ species.

The recovery percentages obtained for each homogenization type are shown in Figure 3.

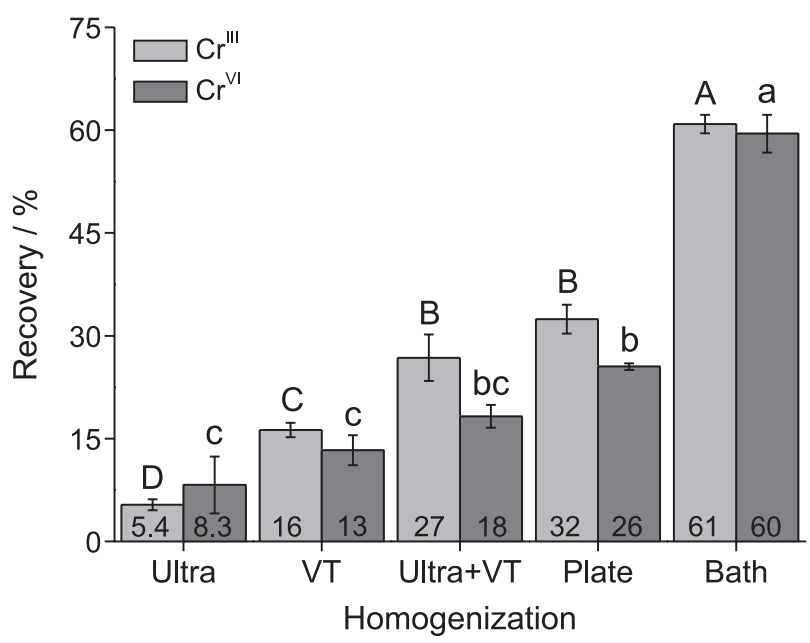

Figure 3. $\mathrm{Cr}^{\mathrm{III}}$ and $\mathrm{Cr}^{\mathrm{VI}}$ recovery percentages using five sample homogenization types as extraction phase made up by EDTA solution in pH 9.5. Observation: Ultra: ultrasonic bath; VT: vortex; Bath: shaking water bath.

It was observed that homogenization using a water bath for $24 \mathrm{~h}$ resulted in a higher recovery percentage for both $\mathrm{Cr}^{\mathrm{III}}$ and $\mathrm{Cr}^{\mathrm{VI}}$ in the sludge sample. This method significantly differed from other homogenization types, so it was chosen for the next steps in this study. This homogenization method was also used to determine $\mathrm{Cr}^{\mathrm{VI}}$ in soils and sediments. ${ }^{33,34}$

The extraction time was the second variable studied for solid-liquid extraction. Four levels were evaluated, as shown in Table 1 . The recovery percentages obtained at each time are shown in Figure 4.

As can be observed, the 16-h and 24-h extraction times did not statistically differ. Therefore, the 16-h time was selected as the best time for the Cr extraction from the sewage sludge samples. A previous work ${ }^{12}$ also used alkaline EDTA solution with this extraction time and obtained recovery percentages below $42.9 \% \mathrm{Cr}$ in organic soils.

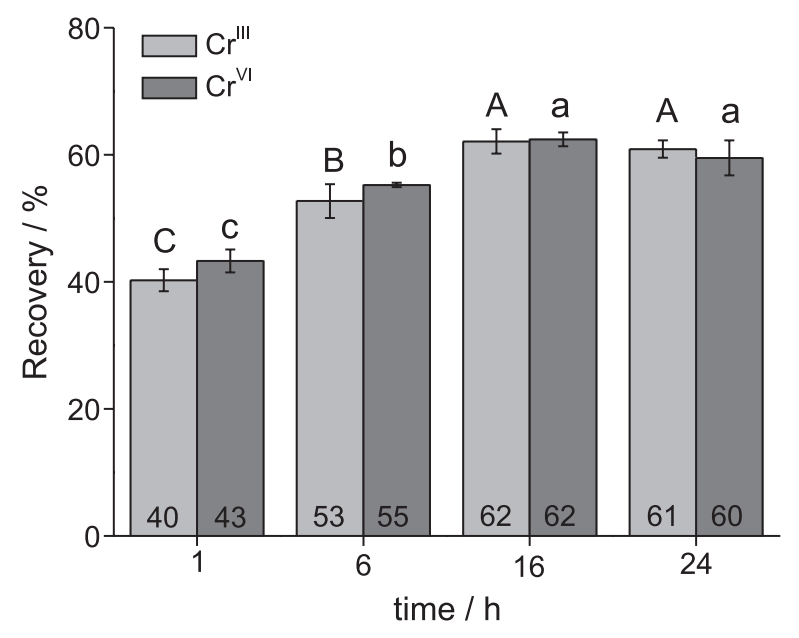

Figure 4. $\mathrm{Cr}^{\mathrm{III}}$ and $\mathrm{Cr}^{\mathrm{VI}}$ recovery percentages in sludge samples using four extraction times in water-bath with stirring.

Three extraction temperatures were evaluated in the last optimization parameter, as shown in Table 1. The recovery percentages obtained at each temperature are shown in Figure 5.

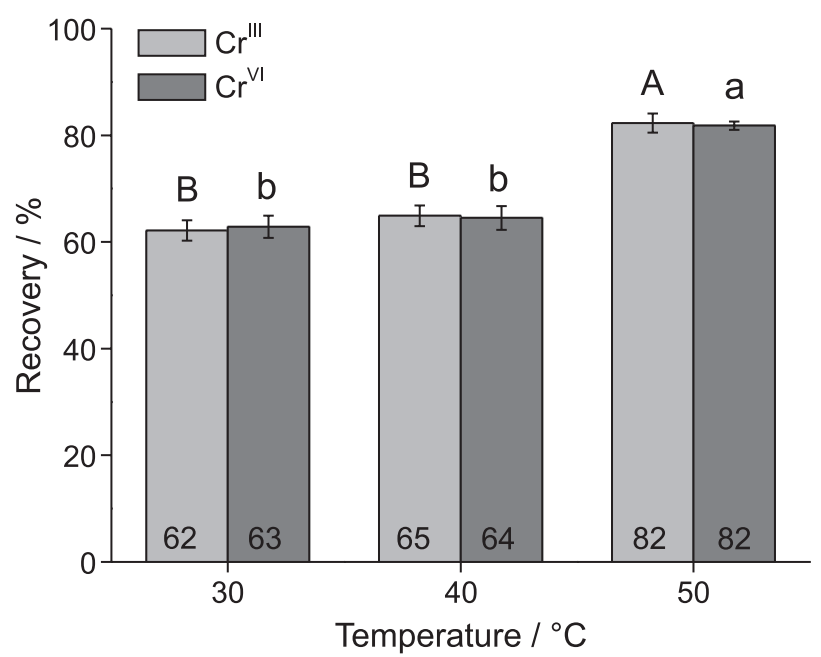

Figure 5. Cr recovery percentages in sludge samples using three temperatures for water-bath extraction in $16 \mathrm{~h}$.

It could be seen that the heating at $50{ }^{\circ} \mathrm{C}$ significantly differed in this parameter from the other evaluated temperatures and showed an increase of about $20 \%$ in the $\mathrm{Cr}$ recovery percentage. Therefore, this temperature was adopted for $\mathrm{Cr}$ extraction from sewage sludge samples. Temperatures between 40 and $70{ }^{\circ} \mathrm{C}$ have already been used for solid-liquid $\mathrm{Cr}^{\mathrm{VI}}$ extraction from sediment and weld smoke samples, with extraction percentages between 14 and $106 \%$ having been obtained. ${ }^{35-37}$

After optimizing these four extraction parameters, it was possible to observe that the $\mathrm{Cr}{ }^{\mathrm{III}}$ recovery percentage was four times higher than the methodology proposed by Guidotti et al. ${ }^{11}$ 


\section{$\mathrm{Cr}^{\text {III }}$ and $\mathrm{Cr}^{\mathrm{VI}}$ speciation by HPLC-ICP-MS/MS}

$\mathrm{Cr}^{\mathrm{III}}$ and $\mathrm{Cr}^{\mathrm{VI}}$ speciation were studied using a standard solution containing both $\mathrm{Cr}$ species which was prepared in the mobile phase and analyzed by HPLC-ICP-MS/MS. The obtained chromatogram is shown in Figure 6 a.

As can be seen, the analyses were performed in a total time of 3.0 min and the retention times of $\mathrm{Cr}^{\mathrm{III}}$ and $\mathrm{Cr}^{\mathrm{VI}}$ were 1.0 and $2.2 \mathrm{~min}$, respectively. On the other hand, an analysis of the extract obtained from both $\mathrm{Cr}^{\mathrm{III}}$ and $\mathrm{Cr}^{\mathrm{VI}}$ fortified sludge sample resulted in a 1.0-min signal chromatogram assigned to $\mathrm{Cr}^{\mathrm{III}}$ (Figure 6b).

Two sewage sludge samples were fortified in order to investigate the absence of $\mathrm{Cr}^{\mathrm{VI}}$ signal in the extract chromatogram; one with only $\mathrm{Cr}^{\mathrm{III}}$ and one with only $\mathrm{Cr}^{\mathrm{VI}}$. Both samples were extracted under the optimized conditions and the obtained chromatograms are shown in Figure 7.

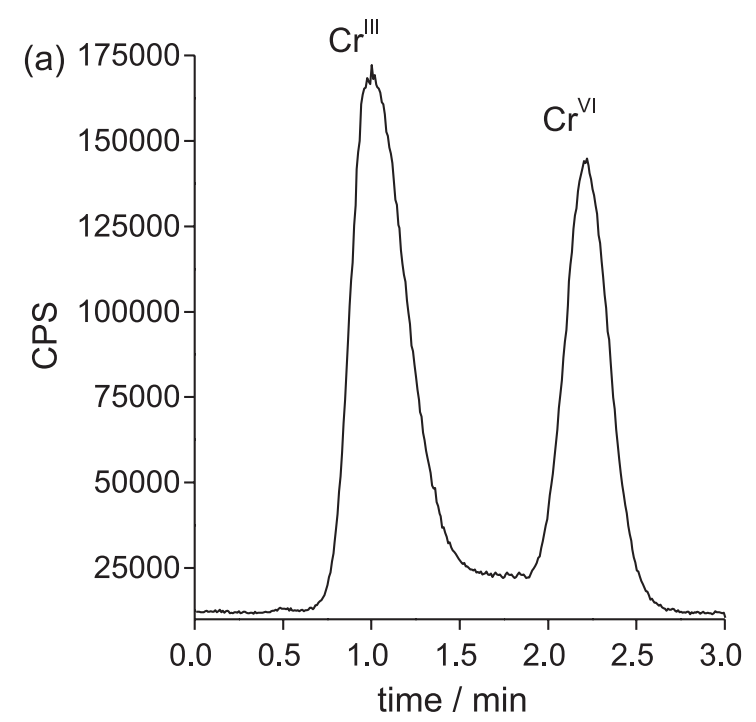

It can be observed that both chromatograms showed only the 1 -min signal for $\mathrm{Cr}^{\mathrm{III}}$. These results indicated that all $\mathrm{Cr}^{\mathrm{VI}}$ was reduced to $\mathrm{Cr}^{\mathrm{III}}$ in the sewage sludge sample or during the extraction process. Thus, the results obtained for $\mathrm{Cr}^{\mathrm{VI}}$ in the optimization step of the extraction method shown in Figures 3, 4 and 5 refer to the detected concentrations of $\mathrm{Cr}^{\mathrm{III}}$.

New experiments were performed in order to show which stage the $\mathrm{Cr}^{\mathrm{VI}}$ reduction occurred in. Therefore, the standard solution containing $\mathrm{Cr}^{\mathrm{III}}$ and $\mathrm{Cr}^{\mathrm{VI}}$ at a concentration of $50 \mu \mathrm{g} \mathrm{L}^{-1}$ was subjected to the same conditions as the optimized method, but without the sewage sludge sample. The obtained extract was analyzed by HPLC-ICP-MS/MS, and the chromatogram is shown in Figure 8.

In this chromatogram it can be observed that the two signals attributed to $\mathrm{Cr}^{\mathrm{III}}$ and $\mathrm{Cr}^{\mathrm{VI}}$ were detected in 1 and $2.2 \mathrm{~min}$, respectively. This study revealed that optimized

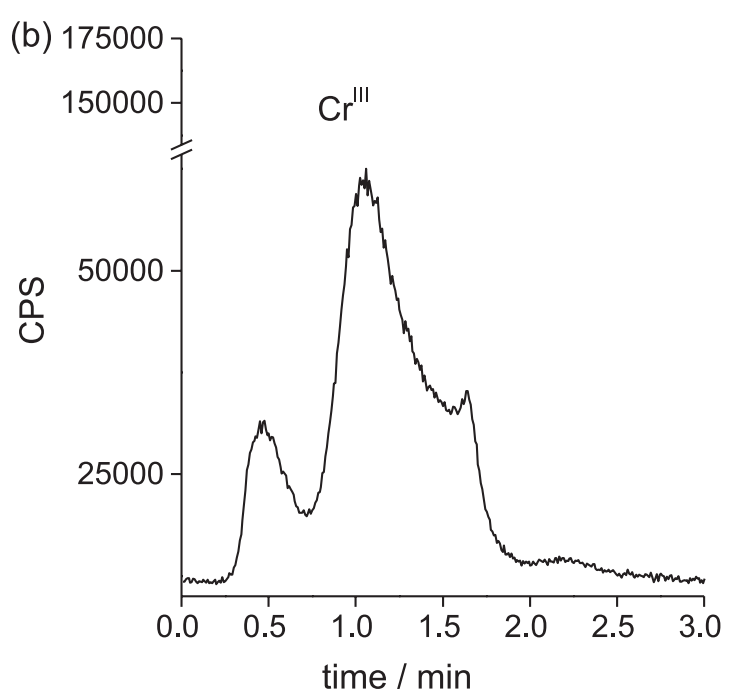

Figure 6. (a) Standard solution chromatograms with $\mathrm{Cr}^{\mathrm{III}}$ and $\mathrm{Cr}^{\mathrm{VI}}$ at $50 \mu \mathrm{g} \mathrm{L}^{-1}$ prepared in the mobile phase, and (b) sewage sludge obtained in optimized extraction conditions.
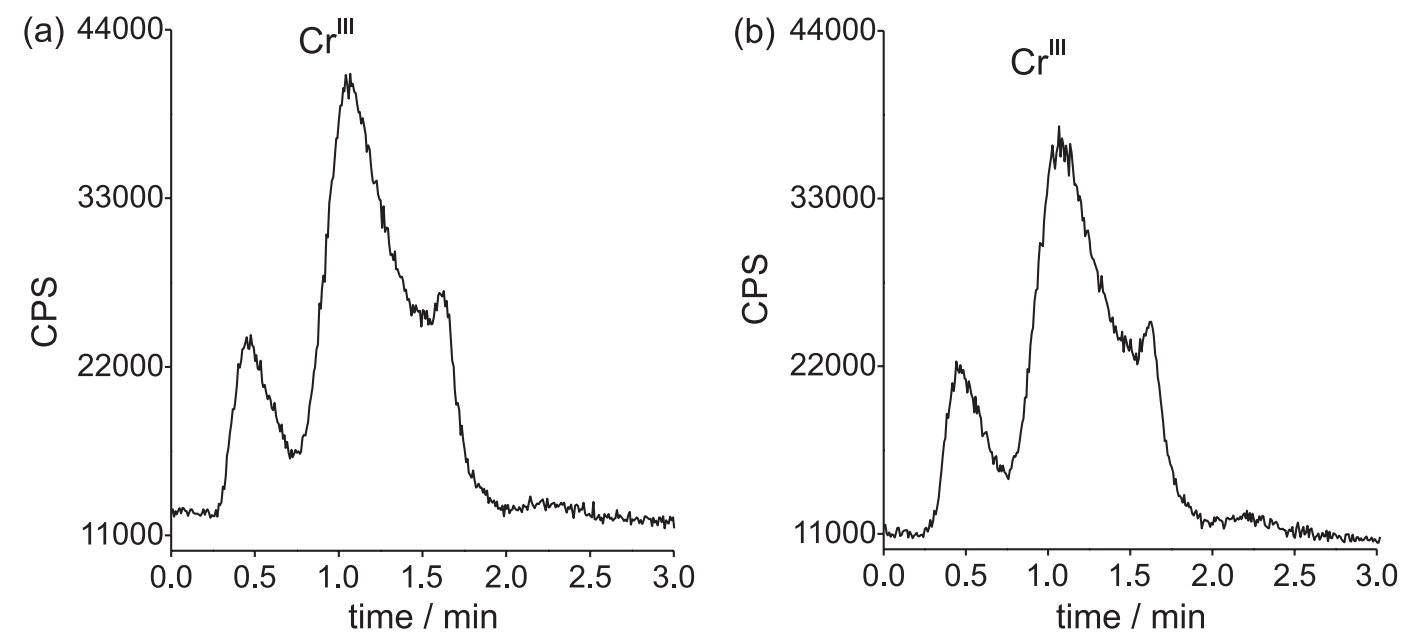

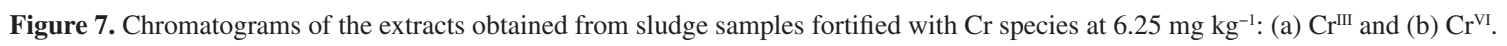




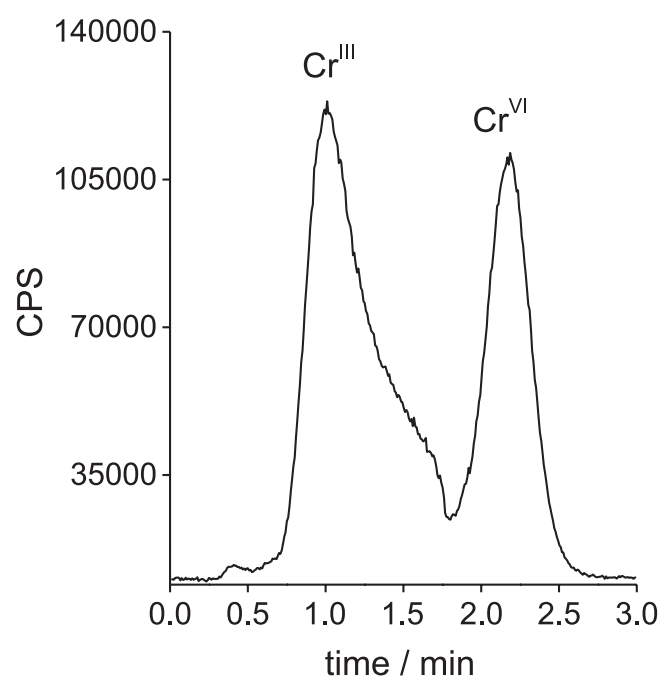

Figure 8. Chromatogram of the standard solution containing $\mathrm{Cr}^{\mathrm{III}}$ and $\mathrm{Cr}^{\mathrm{VI}}$ at $50 \mu \mathrm{g} \mathrm{L} \mathrm{L}^{-1}$, which was submitted to the optimized extraction method without sewage sludge.

extraction conditions did not contribute to reduce $\mathrm{Cr}^{\mathrm{VI}}$ into $\mathrm{Cr}^{\text {III }}$. In addition, the chosen extraction phase promotes the stabilization of $\mathrm{Cr}$ species, as a $\mathrm{pH}$ around 10 makes it difficult to reduce $\mathrm{Cr}^{\mathrm{VI}}$, and EDTA prevents the oxidation or precipitation of $\mathrm{Cr}^{\mathrm{IIII}} .3,6,38$

On the other hand, the sewage sludge presented a chemical composition which allows this type of reaction (Table S1, SI section), because the reduction of $\mathrm{Cr}^{\mathrm{VI}}$ in environmental matrices may occur in the presence of $\mathrm{Fe}^{\mathrm{II}}$ ions, sulfide and organic matter. In addition, the humic and fulvic acids which make up organic matter may also contribute to this reduction reaction. ${ }^{39}$

\section{Extraction method validation}

The method selectivity was evaluated by analyses of (i) mobile phase, (ii) extractor phase and (iii) non-fortified sludge extract (blank) by HPLC-ICP-MS/MS. Based on the chromatograms we concluded that the signal observed at $0.5 \mathrm{~min}$ refers to a matrix component, while the signal at $1.7 \mathrm{~min}$ is a baseline elevation. It is worth mentioning that no signal was observed at the retention time of $2.2 \mathrm{~min}$ during the sewage sludge extract analysis (Figure 7). This result indicates that ${ }^{52} \mathrm{Cr}^{\mathrm{VI}}$ did not show interference in polyatomic ions, for example $\mathrm{ClOH}^{+}(\mathrm{m} / z=52)$, which can be removed by triple quadrupole collision cell.
Bearing in mind that all $\mathrm{Cr}$ in the sludge was in the $\mathrm{Cr}^{\mathrm{III}}$ form, we began the validation step by only using this chemical species. In addition, we chose to directly analyze the extracts by means of ICP-MS/MS, as it was not necessary to separate the $\mathrm{Cr}$ species before the quantification step. The results obtained in validating the optimized method are shown in Table 2.

The LOD and the LOQ were obtained by multiplying the standard deviation of the method blank (extractor phase) by three and ten times, respectively, which was analyzed by ICP-MS/MS in ten repetitions. This strategy was necessary due to the absence of a Cr-free sludge sample. As shown in Table 2, the obtained values were lower than those observed in detection and quantification studies of $\mathrm{Cr}$ in sewage sludge by ICP OES, which were 6.00 and $11.6 \mu \mathrm{g} \mathrm{L}^{-1}$ for LOD and LOQ, respectively. ${ }^{40,41}$

Instrumental linearity was evaluated using standard $\mathrm{Cr}^{\mathrm{III}}$ solutions prepared in the extractor phase at concentrations of $0.2 ; 1.0 ; 10 ; 20 ; 30 ; 40$ and $50 \mu \mathrm{g} \mathrm{L}^{-1}$ in two repetitions. As can be seen in Figure S1 (SI section), the calibration curve was linear in the studied range and presented coefficient of determination $\left(\mathrm{r}^{2}\right)$ greater than 0.99 .

The precision and accuracy of the method were evaluated using $\mathrm{Cr}^{\mathrm{III}}$ fortification/recovery assays at 10 and $50 \mu \mathrm{g} \mathrm{L}^{-1}$ concentrations, with seven replicates at each level. Cr recovery was determined by subtracting the sludge blank contribution in order to avoid overestimating the results. The optimized extraction method was accurate because recovery percentages were within the acceptable range of 70 to $120 \%$ as recommended by IUPAC. ${ }^{29}$ The accuracy was considered adequate, as relative standard deviation values were about three to seven times lower than a maximum value of $20 \%$.

After validating the methodology, we then compared the extraction efficiency of the optimized and validated method with the reference method recommended by the EPA. ${ }^{20}$

\section{Comparison between methods}

A sludge sample was submitted to the optimized extraction method and only $\mathrm{Cr}^{\mathrm{III}}$ was identified in the analyses by HPLC-ICP-MS/MS. Thus, $53.3 \%$ of the metal in the sample was extracted under the optimum conditions. On the other hand, the amount of $\mathrm{Cr}$ extracted was only

Table 2. Results of the Cr ${ }^{\text {III }}$ extraction method validation in sewage sludge by means of ICP-MS/MS

\begin{tabular}{lcccccc}
\hline & \multicolumn{2}{c}{ Calibration data } & & \multicolumn{2}{c}{ Recovery \pm RSD / \% } \\
\cline { 1 - 2 } \cline { 5 - 6 } LOD / $\left(\mu \mathrm{g} \mathrm{L}^{-1}\right)$ & $\mathrm{LOQ} /\left(\mu \mathrm{g} \mathrm{L}^{-1}\right)$ & Range $/\left(\mu \mathrm{g} \mathrm{L}^{-1}\right)$ & $\mathrm{r}^{2}$ & & $10 \mu \mathrm{g} \mathrm{L}^{-1}$ & $50 \mu \mathrm{g} \mathrm{L}^{-1}$ \\
\hline 0.060 & 0.20 & $0.20-50$ & & $73.8 \pm 3$ & $74.4 \pm 7$ \\
\hline
\end{tabular}

LOD: limit of detection; LOQ: limit of quantification; $\mathrm{r}^{2}$ : coefficient of determination; RSD: relative standard deviation. 
$4.09 \%$ when the same sample was submitted to extraction through the EPA 1311 method. ${ }^{20}$ This means that the optimized method had about 13 times higher extraction efficiency than the reference method.

It is noteworthy that the bioavailable $\mathrm{Cr}$ extraction was less than $60 \%$ in both methods. It is likely that $\mathrm{Cr}^{\mathrm{III}}$ is strongly adsorbed on sewage sludge components.

\section{Method applied in real sample}

The optimized and validated method was applied to a sewage sludge sample and showed a $\mathrm{Cr}^{\mathrm{III}}$ concentration of $20.5 \mathrm{mg} \mathrm{kg}^{-1}$. This concentration was less than the acceptable maximum limit of $\mathrm{Cr}^{\mathrm{III}}$ in sewage sludge, which is $500 \mathrm{mg} \mathrm{kg}^{-1}$ according to legislation 80568/4225/91 harmonized with the European Directive. ${ }^{9}$ Previous work ${ }^{40}$ also quantified $\mathrm{Cr}^{\mathrm{III}}$ in sludge samples at lower concentrations than those established by this regulatory organ, with concentrations ranging from 13.5 to $350.7 \mathrm{mg} \mathrm{kg}^{-1}$.

\section{Conclusions}

We have optimized a method for inorganic chromium species in sewage sludge samples. The method was validated through the main figures of merit and it was accurate, precise, linear and presented lower limits of detection and quantification than those mentioned in the literature. Only $\mathrm{Cr}^{\mathrm{III}}$ species was detected in the analysis of sewage sludge extracts by HPLC-ICP-MS/MS, as all $\mathrm{Cr}^{\mathrm{VI}}$ was reduced by the components of the sludge matrix. This method was more efficient than the reference in the bioavailable $\mathrm{Cr}$ extraction because it increased the extraction by 13 times compared to the EPA 1311 method. The $\mathrm{Cr}^{\mathrm{III}}$ concentration quantified in the sludge sample was below the maximum limit acceptable by law 80568/4225/91 harmonized with the European Directive.

\section{Supplementary Information}

Supplementary data are freely available at http://jbcs.sbq.org.br as PDF file.

\section{Acknowledgments}

We thank the National Council for Scientific and Technological Development (CNPq) (project number 420637/2016-8 and 308480/2019-8), the Minas Gerais State Research Support Foundation (FAPEMIG) (APQ01429-16), the Coordination for the Improvement of Higher Education Personnel (CAPES) and the Dean of Research of the Universidade Federal de Minas Gerais (PRPq/UFMG).
We also thank the Instituto de Ciências Agrárias of the Universidade Federal de Minas Gerais (ICA-UFMG) for the infrastructure and execution of this work.

\section{References}

1. Nissim, W. G.; Cincinelli, A.; Martellini, T.; Alvisi, L.; Palm, E.; Mancuso, S.; Azzarello, E.; Environ. Res. 2018, 164, 356.

2. Roy, T.; Biswas, D. R.; Ghosh, A.; Patra, A. K.; Singh, R. D.; Sarkar, A.; Biswas, S. S.; Appl. Soil Ecol. 2019, 136, 116.

3. Tirez, K.; Scharf, H.; Calzolari, D.; Cleven, R.; Kisser, M.; Lück, D.; J. Environ. Monit. 2007, 9, 749.

4. Yanni, A. E.; Stamataki, N. S.; Konstantopoulos, P.; Stoupaki, M.; Abeliatis, A.; Nikolakea, I.; Perrea, D.; Karathanos, V. T.; Tentolouris, N.; Eur. J. Nutr. 2018, 57, 259.

5. Hamilton, E. M.; Young, S. D.; Bailey, E. H.; Watts, M. J.; Food Chem. 2018, 250, 105.

6. Séby, F.; Vacchina, V.; TrAC, Trends Anal. Chem. 2018, 104, 54.

7. Conselho Nacional do Meio Ambiente (CONAMA); Resolução No. 375/2006 de 29/08/2006: Define Critérios e Procedimentos, para o Uso Agrícola de Lodos de Esgoto Gerados em Estações de Tratamento de Esgoto Sanitário e Seus Produtos Derivados, e Dá Outras Providências; DOU No. 167, de 30/08/2006, p. 141-146. Available at http://www2.mma.gov.br/port/conama/ legiabre.cfm?codlegi=506, accessed in June 2020.

8. Kelessidis, A.; Stasinakis, A. S.; Waste Manage. 2012, 32, 1186.

9. European Commission (EC); Final Implementation Report for Directive 86/278/EEC on Sewage Sludge: 2013-2015; Eunomia, ENT, IVL and EPEM, 2018. Available at https:// ec.europa.eu/environment/archives/waste/reporting/pdf/ Final_Implementation_Report_2013_2015_Sewage_Sludge. pdf, accessed in June 2020.

10. Porto, D. S.; Akiba, N.; de Oliveira, M. A. L.; Gaubeur, I.; J. Braz. Chem. Soc. 2017, 28, 266.

11. Guidotti, L.; Abad, S. Q.; Rodríguez-González, P.; Alonso, J. I. G.; Beone, G. M.; Environ. Sci. Pollut. Res. 2015, 22, 17569.

12. Leśniewska, B.; Gontarska, M.; Godlewska-Żyłkiewicz, B.; Water, Air, Soil Pollut. 2017, 228, 274.

13. Novotnik, B.; Zuliani, T.; Ščančar, J.; Milačič, R.; J. Anal. At. Spectrom. 2013, 28, 558.

14. Vacchina, V.; de la Calle, I.; Séby, F.; Anal. Bioanal. Chem. 2015, 407, 3831.

15. Araujo-Barbosa, U.; Peña-Vazquez, E.; Barciela-Alonso, M. C.; Ferreira, S. L. C.; dos Santos, A. M. P.; Bermejo-Barrera, P.; Talanta 2017, 170, 523.

16. Zhang, J.; Guo, W.; Guo, Q.; Jin, L.; Liu, Z.; Hu, S.; RSC Adv. 2017, 7, 50657.

17. Thakur, R.; Tarafder, P. K.; Jha, R. R.; At. Spectrosc. 2018, 39 , 126.

18. Tiwari, S.; Sharma, N.; Saxena, R.; At. Spectrosc. 2018, 39, 151. 
19. Mamatha, P.; Venkateswarlu, G.; Thangavel, S.; Sahayam, A. C.; Swamy, A. V. N.; At. Spectrosc. 2019, 40, 31.

20. United States Environmental Protection Agency (US EPA); Method 1311: Toxicity Characteristic Leaching Procedure; US EPA: Washington, DC, USA, 1992. Available at https://www. epa.gov/sites/production/files/2015-12/documents/1311.pdf, accessed in June 2020.

21. Chen, Z.; Li, J. S.; Poon, C. S.; J. Cleaner Prod. 2018, 171, 1447.

22. Mahdikhani, M.; Khanban, M. R.; Constr. Build. Mater. 2019, 221, 772 .

23. Fu, L.; Shi, S.-Y.; Chen, X.-Q.; Food Chem. 2018, 245, 692.

24. Unceta, N.; Astorkia, M.; Abrego, Z.; Gómez-Caballero, A.; Goicolea, M. A.; Barrio, R. J.; Talanta 2016, 154, 255.

25. Ding, W.; Stewart, D. I.; Humphreys, P. N.; Rout, S. P.; Burke, I. T.; Sci. Total Environ. 2016, 541, 1191.

26. Aguilar, F. J. A.; Wrobal, K.; Lokits, K.; Caruso, J. A.; Alonso, A. C.; Corona, J. F. G.; Wrobel, K.; Anal. Bioanal. Chem. 2008, 392,269

27. Barbosa, É. S.; Cacique, A. P.; de Pinho, G. P.; Silvério, F. O.; J. Environ. Sci. Health, Part A: Toxic/Hazard. Subst. Environ. Eng. 2020, 55, 209.

28. RStudio Statistical Software Program, version 1.0.136; RStudio, USA, 2009-2016.

29. Thompson, M.; Ellison, S. L. R.; Wood, R.; Pure Appl. Chem. 2002, 74, 835 .

30. United States Environmental Protection Agency (US EPA); Method 3051A (SW-846): Microwave Assisted Acid Digestion of Sediments, Sludges, and Oils, Revision 1; US EPA:
Washington, DC, USA, 2007. Available at https://www.epa.gov/ sites/production/files/2015-12/documents/3051a.pdf, accessed in June 2020.

31. Wolle, M. M.; Rahman, G. M. M.; Kingston, H. M. S.; Pamuku, M.; J. Anal. At. Spectrom. 2014, 29, 1640.

32. United States Environmental Protection Agency (US EPA); Method 3060A: Alkaline Digestion for Hexavalent Chromium; US EPA: Washington, DC, USA, 1996. Available at https:// www.epa.gov/sites/production/files/2015-12/documents/3060a. pdf, accessed in June 2020.

33. Mandiwana, K. L.; Talanta 2008, 74, 736.

34. Delay, M.; Mangold, S.; Sembritzki, R.; Frimmel, F. H.; Aquat. Geochem. 2015, 21, 313.

35. Ndung'u, K.; Djane, N. K.; Malcus, F.; Mathiasson, L.; Analyst 1999, 124, 1367.

36. Ščančar, J.; Berlinger, B.; Thomassen, Y.; Milačič, R.; Talanta 2015, 142, 164.

37. Jabłońska-Czapla, M.; Int. J. Anal. Chem. 2015, 2015, 171478.

38. Cuello, S.; Entwisle, J.; Benning, J.; Liu, C.; Coburn, S.; McAdam, K. G.; Braybrook, J.; Goenaga-Infante, H.; J. Anal. At. Spectrom. 2016, 31, 1818.

39. Leśniewska, B.; Godlewska-Zyłkiewicz, B.; Molecules 2019, 24, 1172.

40. Spanos, T.; Ene, A.; Karadjova, I. B.; Rom. J. Phys. 2015, 60, 237.

41. Biro, M.; Kavšek, D.; Karasiński, J.; Szwarczewski, P.; Bulska, E.; Vončina, D. B.; Cent. Eur. J. Chem. 2014, 12, 687.

Submitted: January 23, 2020

Published online: June 23, 2020 